\title{
Effectiveness of the Flipped Classroom Strategy in Teaching Qur'an Recitation Skills and Attitude Towards It among First Grade Students in Saudi Arabia
}

\author{
Ali Tared Aldossari* and Munirah Saud Alhamam \\ Imam Abdulrahman Bin Faisal University, College of Education, Curriculum \& \\ Instruction Department, Dammam, Saudi Arabia \\ https://orcid.org/0000-0001-6329-2387 \\ https://orcid.org/0000-0001-7379-5842
}

\begin{abstract}
This study aims to identify the effectiveness of the flipped classroom strategy in developing the skills of reciting the Holy Qur'an, and the attitude towards the strategy among first grade intermediate school female students. The research sample was a random sample of 48 intermediate female students divided into two 24-student groups: a control group and an experimental group. To collect data according to the quasi-experimental design method, a note card was designed to measure recitation skills of the Qur'an, and a scale developed to record attitude towards the flipped classroom strategy. The note card was applied to the research sample. The results revealed a statistically significant difference $(a \leq 0.05)$ in favor of the experimental group between the average scores of the two groups in the post-application of the note card. The results also showed a statistically significant difference between the average scores of the experimental group $(\alpha \leq 0.05)$ in the post-application of the attitude scale towards the flipped classroom strategy. Lastly, the results showed a statistically significant correlation between the skills of reciting the Holy Qur'an and the attitude towards the flipped classroom strategy among first grade intermediate female students. Based on these results, we present a number of recommendations and suggestions, including expanding the application of the flipped classroom strategy to other age groups and different courses.
\end{abstract}

Keywords: effectiveness, female students; flipped classroom strategy; intermediate school; reciting skills; Qur'an recitation; student performance

*Corresponding Author: Ali Tared Aldossari; Email: ataldossari@iau.edu.sa 


\section{Introduction}

Many recent studies have stressed the importance of the flipped classroom model in the 21st century due to the information communication technology that facilitates two-way online communication with students, besides fostering a new methodological proposal that requires a change in student performance in and out of the classroom (Prieto et al., 2021). Furthermore, student engagement in the educational process is associated with engagement in academic and nonacademic activities rather than mere participation and interest in these activities (Hava, 2020). Realizing such importance, the Saudi Ministry of Education has considered teaching the Holy Qur'an at all stages of education, from primary school to university, through applying the flipped classroom model. The document on teaching legal sciences in the intermediate stage contains a set of goals, including the recitation of the Holy Qur' an and the application of Quranic recitation rules (Kingdom of Saudi Arabia [KSA]. Ministry of Education, 2007).

The flipped classroom strategy focuses on one-to-one learning and comprises many methods, forms, and types of student-centered learning, including differentiated teaching and research. When these methods are combined with the concept of flipped learning, strategies can be obtained that can be practically applied. The flipped classroom is centered on the student (Bergman \& Sams, 2015), which plays a major role in developing the student's attitudes towards it. The student's role becomes positive in the classroom through the availability of activities and practical exercises, while the content sent home helps to deepen understanding and mastery of the material (Al-Rous et al., 2016). The relationship of the flipped classroom strategy to the skills of reciting the Holy Qur'an is clear in that it allows students to be trained in advance, thus enabling them to interact with the teacher in a more constructive way. This strengthens their performance and allows more time for practice.

From the above, it is evident that the flipped classroom strategy in teaching the Holy Qur'an has positive effects on students' skills and performance. Therefore, we sought to investigate the development of skills in reciting the Holy Qur'an among intermediate school female students using the flipped classroom strategy, and their attitude towards it. Accordingly, the study seeks to discover the effectiveness of the flipped classroom strategy in developing each of the Holy Qur' an recitation skills and the attitude of first grade intermediate female students towards the strategy. Aside from this, the study seeks to identify the correlation between the skills of reciting the Holy Qur' an and the attitude towards the flipped classroom strategy among first grade intermediate female students.

From our point of view, the study is important as it provides a theoretical framework for the flipped classroom strategy, the skills of reciting the Holy Qur'an, and the attitude towards this strategy, in order to enrich scientific research. From a practical point of view, the study's findings will benefit various stakeholders, including curriculum planners, educational supervisors, and schoolteachers. The study is intended to provide a procedural guide to the flipped classroom strategy with a view to keeping pace with modern technological 
attitudes in teaching methods, in line with the digital transformation in education stipulated in the KSA's Vision 2030 (KSA, 2030).

\section{Main Research Question}

We address the study problem with the following main question: What is the effectiveness of the flipped classroom strategy in developing the skills of reciting the Holy Qur'an among intermediate school female students, and what is their attitude towards it?

\subsection{Subsidiary research questions}

The following subsidiary questions have been formulated in support of the main research question:

1. What is the effectiveness of the flipped classroom strategy in developing the skills of reciting the Holy Qur'an among first grade intermediate female students?

2. What is the effectiveness of the flipped classroom strategy in developing students' attitudes towards this strategy among first grade intermediate female students?

3. What is the correlation between the skills of reciting the Holy Qur'an and the attitude towards this strategy?

\subsection{Research hypotheses}

This study seeks to verify the following hypotheses:

1. There is no statistically significant difference (at the $\alpha \leq 0.05$ level) between the average scores of the experimental and control groups in the post-application of the note card recording skills in reciting the Holy Qur'an for first grade intermediate female students.

2. There is no statistically significant difference (at the $\alpha \leq 0.05$ level) between the average scores of the experimental group in the pre- and post-application of the scale of attitude towards the strategy for first grade intermediate female students.

3. There is no statistically significant correlation (at the $a \leq 0.05$ level) between the skills of reciting the Holy Qur'an and the attitude towards the flipped classroom strategy among first grade intermediate female students after teaching them using the flipped classroom strategy.

\subsection{Research aims}

This study aims to:

1. Determine the effectiveness of the flipped classroom strategy in teaching Qur'an recitation skills among first grade female students in Saudi Arabia.

2. Determine the attitude towards the flipped classroom strategy among first grade female students in Saudi Arabia

3. Determine the nature of the correlation between the flipped classroom strategy in teaching Qur'an recitation skills and the attitude towards it among first grade female students in Saudi Arabia. 


\subsection{Research importance}

\subsubsection{Theoretical importance}

This is the first study to investigate the effectiveness of the flipped classroom strategy in teaching Qur'an recitation skills, and the attitude towards it among first grade students in KSA. It evaluates the importance of involving students in the educational process and focuses on developing their participation.

\subsubsection{Practical importance}

This study aims to direct teachers to apply the flipped classroom strategy in teaching Qur'an recitation skills. Applying the flipped classroom strategy encourages more positive participation among students.

\section{Terminology Used in this Study}

The following terms are used in this study:

- The flipped classroom strategy involves assigning certain tasks to students to be prepared in advance and before attending a class.

- Qur'an recitation refers to the way of reading the Qur'an by observing certain rules.

- Intonation skills are rules of sound pitch in reciting the Qur'an.

- Tajweed is a set of linguistic and pronunciation rules used in reciting the Qur'an in the right way.

\section{Theoretical Literature and Related Studies}

The flipped classroom strategy is one of the teaching methodologies that include three basic components of the classroom environment: before entering the classroom, while in the classroom, and after completing the classroom activities. In this strategy, before joining the classroom, students are exposed to the contents of the course through watching educational videos online or reading textbooks, making the subject matter accessible. The third component of learning is the postteaching stage, where student learning is assessed. The great advancements in communication technology have facilitated the application of the flipped classroom, which is also known as inverted teaching and flipped learning. These are all intended to divide learning tasks between home and school, where the teacher prepares the lesson to be studied at home and sends it to students using a modern means of communication. Class time is allocated to tackling the activities assigned to students. The Board of Directors of the Flipped Learning Network (FLN) defined flipped learning as "a pedagogical approach in which direct instruction moves from the group learning space to the individual learning space, and the resulting group space is transformed into a dynamic, interactive learning environment where the educator guides students as they apply concepts and engage creatively in the subject matter" (UC Riverside, 2021).

\subsection{Importance of the flipped classroom strategy}

The flipped classroom strategy is one of the ways of confronting the problem of students' absenteeism by increasing activities as well as overcoming the distance between their school and home (Bergmann \& Sams, 2012). To support this, the FLN was established and has grown in recent years. 
Baker was the first to publish information on the flipped classroom strategy in 1982. He attempted to provide the scientific content of the materials he was presenting outside the classroom through electronic means, where he faced some challenges (Smith, 2015).

Salman Khan is considered one of the pioneers of the flipped classroom strategy. He started experimenting with it in 2004 and posted videos on YouTube that include minilectures on several disciplines (Merrill, 2015). Of course, rapid technological developments have had a significant impact on teachers' efforts to take advantage of modern communication, especially as students have been influenced by these developments and their interaction with them. In addition, the possibility of continuously updating the learning content has had the greatest impact in strengthening the relationship between teachers and students (Fulton, 2012). Perhaps the primary reason for using the flipped classroom strategy is to avoid the problems of the traditional method of teaching and the loss of motivation among students through feeling marginalized in the classroom.

Many empirical studies have been conducted on flipped learning. Matar (2018) aimed to identify the impact of a computerized program on developing Holy Qur'an recitation skills at the University College Centre in Gaza. In addition, Al-Zahrani (2018) investigated the effect of employing mind maps in the elearning environment on developing certain skills in reciting the Holy Qur'an among female students at the Faculty of Sciences and Literature in Al-Baha University.

Studies have indicated weaknesses in skills of reciting the Holy Qur' an (Al-Salim, 2017; Al-Zoubi, 2013). Shaheen et al. (2015) attributed the situation to the use of traditional methods, the failure to use teaching methods that focus on performance, and neglect of the use of modern technologies.

We interviewed four female educational supervisors, who confirmed that female students in most schools that they supervised showed weaknesses in the skills of reciting the Holy Qur'an. In light of this, Abanmi (2016) recommended the need to apply the flipped classroom strategy in schools in the KSA.

Many studies worldwide have investigated the flipped classroom strategy and the development of attitudes towards it. Marlow (2012) aimed to identify the impact of using the flipped classroom strategy on academic achievement, and Herreid and Schiller (2013) revealed the importance of the flipped classroom approach in teaching. Furthermore, Aaron (2015) aimed to identify the effectiveness of the flipped learning model in the achievement and performance of e-learning skills among undergraduate students at the Faculty of Education in Al-Baha University, while Johnson (2012) investigated the effect of flipped classrooms on student and teacher attitudes, student achievement, and the nature of classroom questions. In 2016, Al-Rous et al. (2016) identified the effectiveness of the flipped classroom in the development of academic achievement among female students in the Faculty of Education at Qatar University, in addition to determining the attitudes of the experimental group towards the flipped classroom. 


\subsection{Challenges facing the flipped classroom strategy}

The flipped classroom strategy faces many challenges related either to the teacher or the student.

\subsubsection{Challenges related to the teacher}

Caudill (2014) believed that teaching in the flipped classroom demands more time to prepare recorded content, design electronic materials, and prepare videos or other resources. Teachers require training for this and benefit from sharing their experiences with one another. We believe that this challenge can be overcome by creating a new culture that keeps pace with current technological developments. Training may convince teachers of the possibility of applying this strategy.

\subsubsection{Challenges related to the student}

Challenges related to the student are mainly related to the unavailability of modern technological tools, along with lack of sufficient experience in dealing with such tools. This can be overcome through the teacher's support for the student, strengthened by assigning grades to the student's activity in the classroom and accounting for individual differences so that the student enjoys learning through fulfilling their inclinations and interests. As for internet availability and the lack of necessary devices for all students, we see the possibility of overcoming this by using the learning resource room before entering the classroom (Huu Vuong et al., 2018).

\subsection{Attitude towards the flipped classroom}

Attitude is one of the influential elements in student behavior and motivation. It is a system of responses that reflects students' interests and beliefs about a particular topic, whether positively or negatively. Attitudes towards learning play a critical role in teaching and performance, reflecting positively on the level of the student and improving the quality of education that they receive (Al-Juhani, 2017).

We believe that the flipped method leads to the formation of positive psychological attitudes among students. This is due to its effect on social interaction and cooperative work with their colleagues, thus affecting their ability to adapt and respond to the classroom environment.

Attitudes are tendencies that qualify the student's specific behavioral patterns towards certain people, ideas, or situations, and they constitute a complex system in which a large group of diverse variables interact. Perhaps the best way to determine the nature of attitudes is to look at them through the functions of their components and characteristics (Nashawati, 2003).

The study of Al-Harthy (2012) has confirmed that attitude consists of three components. The emotional component refers to the nature of the relationship between the subject and other goals that the learner considers important. The cognitive component of attitude involves the information, facts, ideas, and beliefs related to the subject that are available to the learner. Finally, the behavioral component describes the learner's tendency to behave positively or negatively towards a subject. According to Siddiq (2012), attitudes may be: strong, constant, 
and unchanging; weak and can be abandoned; positive in support of an idea or a subject; negative against an idea or a subject; or collective or individual.

In reviewing references on measures of attitude, it was found that the best way to measure the attitude towards the flipped classroom strategy was the Likert scale. Al-Nafi'i (2007) confirmed that this collective assessment method is the most popular method for measuring attitude because it does not require as much time and effort as other methods and leads to results similar to those yielded by other scales.

\section{Research Design}

This research used the experimental method with a quasi-experimental design. This was the most appropriate as it achieved the study aims by measuring the independent variable (the flipped classroom strategy) against the dependent variables (skills of reciting the Holy Qur'an, and attitude towards this strategy).

The research relied on the design based on an experimental and a control group, and a pre- and post-measurement for the two groups. The design is clarified as shown in Table 1.

Table 1: Quasi-experimental design of the research

\begin{tabular}{llll}
\hline Research group & Pre-experiment & Type of teaching & Post-experiment \\
\hline Experimental group & Note card & Flipped classroom & Note card \\
& + & strategy & + \\
\cline { 3 - 3 } Control group & Attitude scale & Traditional method & Attitude scale \\
& towards the & & $\begin{array}{l}\text { towards the } \\
\text { strategy }\end{array}$ \\
& strategy & &
\end{tabular}

\subsection{Participants}

The study population consisted of all female Arabic-speaking students in the first intermediate grade in public and private schools in Dammam. According to the Dammam Education Office statistical guide 2020-2021, this population consisted of 3460 individuals at the time of study.

The sample for this study consisted of 48 intermediate school female students, who were selected randomly from Al-Hussan Model School. The school was purposely chosen as it is one of the schools affiliated with the Classera platform, an online platform that has been adopted for use in a variety of learning environments in K-12 schools in Saudi Arabia. The experimental and control groups were chosen by random lottery, each consisting of 24 students.

\subsection{Instruments and data collection techniques}

The research tools and experimental processing materials consisted of the following:

1. A note card to measure the skills of reciting the Holy Qur' an for first grade intermediate female students, prepared by us. The card included the skills of intonation, fluency, and reciting. 
2. A scale of attitude towards the flipped classroom strategy, prepared by us. The scale measured keenness to use the flipped classroom strategy, the importance of learning using the flipped classroom strategy, and enjoyment of learning based on the flipped classroom strategy.

3. The teacher's guide to teaching using the flipped classroom strategy.

\subsection{Data analysis}

5.3.1 Note card to measure the skills of reciting the Holy Qur'an for first grade intermediate female students

The note card was designed to measure the performance of reciting the Holy Qur'an among first grade female students. The design took into consideration previous studies and literature related to the skills of reciting the Qur'an, the objectives of teaching recitation of the Qur'an, and growth characteristics of intermediate school female students. The card recorded three main skills: observing rules of intonation (ten subskills), fluency (three subskills), and recitation (four subskills).

Performance was measured according to a verbal rating scale, subject to a triple gradation (excellent - good - bad), corresponding to quantitative ratings $(2-1-0)$, respectively. Surat Al-Naml was the subject of the evaluation because it has the most rules of intonation.

Face validity of the note card (arbitrators)

The note card was presented in its initial form to a group of experts and arbitrators, including faculty members, educational supervisors, and teachers, at the Ministry of Education. The arbitrators evaluated the note card in terms of various factors. They checked the extent to which the subskills are consistent with the main skills, and the suitability of these skills for female intermediate school students. In addition, they made suggestions for deletions or additions and made other relevant notes and suggestions. The arbitrators' opinions were all taken into consideration.

\section{Note card exploratory experiment}

The note card was tested on a group of 34 second grade female students in the Fifth Intermediate School in Dammam during the first semester of 2021to calculate: 1) the internal consistency coefficients of the tool for the Holy Quran recitation skills and 2) stability of observation.

The internal consistency for this study relates to the strength of correlation between the different skills and their subskills. The tool was tested on 34 female students. The Pearson correlation coefficient was calculated between the degrees of each of the subskills of the note card with the main skill to which it belongs. The results are shown in Table 2. 
Table 2: Correlation coefficients for each of the subskills of the note card with the main skill to which it belongs

\begin{tabular}{|c|c|c|c|c|c|c|c|c|c|c|c|}
\hline \multicolumn{6}{|c|}{ Intonation skill } & \multicolumn{3}{|c|}{ Fluency skill } & \multicolumn{3}{|c|}{ Reciting skill } \\
\hline ż & 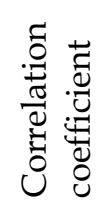 & 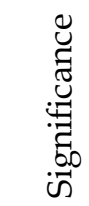 & $\dot{z}$ & 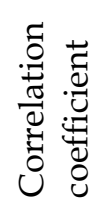 & 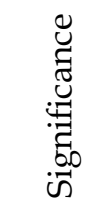 & $\dot{z}$ & 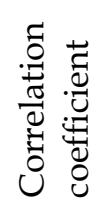 & 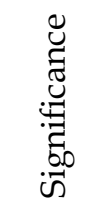 & $\dot{z}$ & 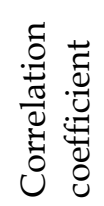 & 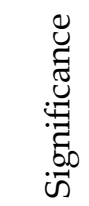 \\
\hline 1 & 0.724 & 0.01 & 6 & 0.851 & 0.01 & 11 & 0.774 & 0.01 & 14 & 0.760 & 0.01 \\
\hline 2 & 0.714 & 0.01 & 7 & 0.848 & 0.01 & 12 & 0.810 & 0.01 & 15 & 0.892 & 0.01 \\
\hline 3 & 0.679 & 0.01 & 8 & 0.897 & 0.01 & 13 & 0.916 & 0.01 & 16 & 0.758 & 0.01 \\
\hline 4 & 0.813 & 0.01 & 9 & 0.884 & 0.01 & -- & -- & -- & 17 & 0.904 & 0.01 \\
\hline 5 & 0.835 & 0.01 & 10 & 0.844 & 0.01 & -- & -- & -- & -- & -- & -- \\
\hline
\end{tabular}

As seen in the table, all correlation coefficients were statistically significant at the significance level (0.01), which confirms that all the subskills of the note card had a high degree of internal validity.

Regarding stability of observation, we tested the tool on a pilot sample of 34 female students using Cronbach's alpha method. Cronbach's alpha coefficient (a) was used to calculate the stability of the main skills and the total score of the note card. This was carried out using the Statistical Package for Social Sciences (SPSS) program for the data we obtained from the pilot sample. The results are shown in Table 3.

Table 3: Note card stability results as per Cronbach's alpha method

\begin{tabular}{lll}
\hline Key skill of note card & No. of subskills & Stability coefficient \\
\hline Intonation skill & 10 & 0.941 \\
\hline Fluency skill & 3 & 0.783 \\
\hline Reciting skill & 4 & 0.852 \\
\hline Total mark of the card & 17 & 0.951 \\
\hline
\end{tabular}

As seen in the table, all values confirm that the note card had a high degree of stability.

Two female colleagues participated with us in observing the Qur'an reading skills of twelve female students in the pilot sample. They recorded their observations regarding the note card indicators, and the Cooper equation was used to calculate the percentage of agreement between the two observers (Cooper, 1973). The results are shown in Table 4.

Table 4: Results of note card stability using observers-agreement method $(\mathrm{N}=12)$

\begin{tabular}{llll}
\hline Key skill of note card & $\begin{array}{l}\text { No. of } \\
\text { agreements }\end{array}$ & $\begin{array}{l}\text { No. of } \\
\text { differences }\end{array}$ & $\begin{array}{l}\text { Agreement } \\
\text { coefficient }\end{array}$ \\
\hline Intonation skill & 116 & 4 & $96.7 \%$ \\
\hline Fluency skill & 34 & 2 & $94.4 \%$ \\
\hline Reciting skill & 45 & 3 & $93.8 \%$ \\
\hline Total mark of the card & 195 & 9 & $95.6 \%$ \\
\hline
\end{tabular}


Table 4 shows that the coefficients of agreement between the two observers $(96.7 \%, 94.4 \%$, and $93.8 \%)$ and the overall agreement coefficient $(95.6 \%)$ were high.

5.3.2 Attitude scale towards flipped classroom strategy for first grade intermediate female students

This scale consisted of 37 items, divided into three dimensions: 1) keenness to use the flipped classroom strategy; 2) the importance of learning using the flipped classroom strategy; and 3) enjoyment of learning based on the flipped classroom strategy. The scale was built with the help of many relevant research studies, considering the simplicity of the statements and the growth characteristics of intermediate school female students. The statements were in the form of positive and negative statements according to the triple Likert scale (agree, somewhat agree, disagree), corresponding to numerical scores $(2-1-0)$.

\section{Validity of the scale contents (arbitrators)}

This scale was presented in its initial form to a group of experts and arbitrators, including faculty members, educational supervisors, and teachers, at the Ministry of Education for evaluation. Factors for evaluation included: correctness and clarity of language; consistency of sub-statements with the dimension they belong to; and suggestions for deletions or additions. The arbitrators' opinions were all taken into consideration.

We conducted a pilot experiment to measure attitude towards the strategy. The pilot test was conducted on 34 first grade intermediate female students in the Fifth Intermediate School in Dammam, affiliated to the Education Department in the Eastern province. The experiment showed the clarity of the scale's instructions and the appropriateness of the time allotted to it.

Three validity parameters were tested: 1 ) the internal consistency coefficients of attitudes towards the strategy; 2) discriminant validity; and 3) reliability of the attitude scale towards the strategy. First, the internal consistency coefficients of attitude towards the strategy were determined. This relates to the strength of correlation between the degrees of each statement on the Flipped Class Strategy Scale, each dimension of the scale, as well as the total score of the scale using the Pearson correlation coefficient. Table 5 shows the results. 
Table 5: Correlation coefficients between each statement of the Flipped Class Strategy Scale with its dimension

\begin{tabular}{|c|c|c|c|c|c|c|c|c|}
\hline \multicolumn{3}{|c|}{$\begin{array}{l}\text { First dimension: } \\
\text { Keenness to use the } \\
\text { flipped classroom } \\
\text { strategy in the learning } \\
\text { process }\end{array}$} & \multicolumn{3}{|c|}{$\begin{array}{l}\text { Second dimension: } \\
\text { Importance of the flipped } \\
\text { classroom strategy }\end{array}$} & \multicolumn{3}{|c|}{$\begin{array}{l}\text { Third dimension: } \\
\text { Enjoyment of learning } \\
\text { based on the flipped } \\
\text { classroom strategy }\end{array}$} \\
\hline 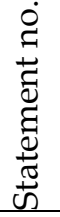 & 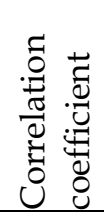 & 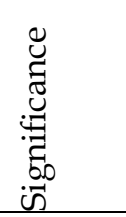 & 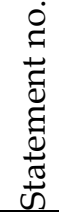 & 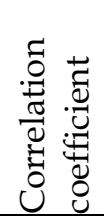 & 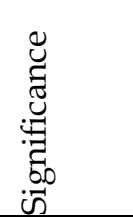 & 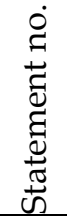 & 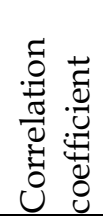 & 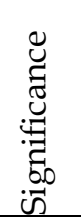 \\
\hline 1 & 0.270 & No sig. & 10 & 0.538 & 0.01 & 24 & 0.611 & 0.01 \\
\hline 2 & 0.604 & 0.01 & 11 & 0.611 & 0.01 & 25 & 0.513 & 0.01 \\
\hline 3 & 0.637 & 0.01 & 12 & 0.778 & 0.01 & 26 & 0.782 & 0.01 \\
\hline 4 & 0.747 & 0.01 & 13 & 0.689 & 0.01 & 27 & 0.651 & 0.01 \\
\hline 5 & 0.655 & 0.01 & 14 & 0.407 & 0.05 & 28 & 0.585 & 0.01 \\
\hline 6 & 0.640 & 0.01 & 15 & 0.716 & 0.01 & 29 & 0.629 & 0.01 \\
\hline 7 & 0.731 & 0.01 & 16 & 0.594 & 0.01 & 30 & 0.826 & 0.01 \\
\hline 8 & 0.592 & 0.01 & 17 & 0.517 & 0.01 & 31 & 0.763 & 0.01 \\
\hline \multirow[t]{6}{*}{9} & 0.667 & 0.01 & 18 & 0.567 & 0.01 & 32 & 0.682 & 0.01 \\
\hline & & & 19 & 0.731 & 0.01 & 33 & 0.614 & 0.01 \\
\hline & & & 20 & 0.194 & No sig. & 34 & 0.667 & 0.01 \\
\hline & & & 21 & 0.569 & 0.01 & & & \\
\hline & & & 22 & 0.735 & 0.01 & & & \\
\hline & & & 23 & 0.557 & 0.01 & & & \\
\hline
\end{tabular}

Note: sig. - significance

The correlation coefficients of the three dimensions have statistical significance at 0.01 , except for statement 1 in the first dimension and statement 20 in the second dimension, which were not statistically significant and were therefore removed.

Second, the discriminant validity of the scale was confirmed by arranging the participants' scores on the scale in descending order, according to the total score achieved by each of them in each of the scale dimensions. From this, the upper and lower groups of nine participants each were identified, each representing $27 \%$ of the sample. Finally, the discriminant validity was determined using the MannWhitney $U$ test to identify the significance of differences between the scores of the two groups. The results are shown in Table 6. 
Table 6: Discriminant validity between low and high scores on the attitude scale towards the flipped classroom strategy

\begin{tabular}{|c|c|c|c|c|c|c|c|}
\hline Scale dimension & Group & No. & $\begin{array}{l}\text { Total } \\
\text { rank }\end{array}$ & $\begin{array}{l}\text { Average } \\
\text { rank }\end{array}$ & $\mathrm{U}$ test & $\begin{array}{l}\text { Sig. } \\
\text { level }\end{array}$ & Stat. sig. \\
\hline First dimension: & Upper & 9 & 123.50 & 13.72 & \multirow[t]{2}{*}{2.50} & \multirow[t]{2}{*}{0.001} & \multirow{2}{*}{$\begin{array}{l}\text { Sig. at } \\
0.01\end{array}$} \\
\hline $\begin{array}{l}\text { Keenness to use } \\
\text { the flipped } \\
\text { classroom } \\
\text { strategy in the } \\
\text { learning process }\end{array}$ & Lower & 9 & 47.50 & 5.28 & & & \\
\hline \multirow{2}{*}{$\begin{array}{l}\text { Second } \\
\text { dimension: } \\
\text { Importance of the } \\
\text { flipped classroom } \\
\text { strategy }\end{array}$} & Upper & 9 & 126.00 & 14.00 & \multirow[t]{2}{*}{0.00} & \multirow[t]{2}{*}{0.00} & \multirow{2}{*}{$\begin{array}{l}\text { Sig. at } \\
0.01\end{array}$} \\
\hline & Lower & 9 & 45.00 & 5.00 & & & \\
\hline \multirow[b]{2}{*}{$\begin{array}{l}\text { Third dimension: } \\
\text { Enjoyment of } \\
\text { learning based on } \\
\text { the flipped } \\
\text { classroom } \\
\text { strategy }\end{array}$} & Upper & 9 & 224.00 & 13.78 & \multirow[t]{2}{*}{2.00} & \multirow[t]{2}{*}{0.001} & \multirow{2}{*}{$\begin{array}{l}\text { Sig. at } \\
0.01\end{array}$} \\
\hline & Lower & 9 & 47.00 & 5.22 & & & \\
\hline \multirow{2}{*}{$\begin{array}{l}\text { Total mark of the } \\
\text { attitude scale }\end{array}$} & Upper & 9 & 126.00 & 14.00 & \multirow[t]{2}{*}{0.00} & \multirow[t]{2}{*}{0.00} & \multirow{2}{*}{$\begin{array}{l}\text { Sig. at } \\
0.01\end{array}$} \\
\hline & Lower & 9 & 45.00 & 5.00 & & & \\
\hline
\end{tabular}

Note: sig. - significant/significance

Table 6 shows that the ' $U$ ' values of the Mann-Whitney $U$ test were statistically significant at 0.01 between the two groups on all dimensions of the scale, which confirms the validity of the scale to a high degree.

Third, the reliability of the attitude scale towards the flipped classroom strategy was verified using Cronbach's alpha method, with the results shown in Table 7.

Table 7: Stability of the attitude scale towards the strategy

\begin{tabular}{lll}
\hline \multicolumn{1}{c}{ Dimension of attitude scale } & $\begin{array}{l}\text { No. of } \\
\text { statements }\end{array}$ & $\begin{array}{l}\text { Stability } \\
\text { coefficient }\end{array}$ \\
\hline $\begin{array}{l}\text { First dimension: } \\
\begin{array}{l}\text { Keenness to use the flipped classroom strategy } \\
\text { in the learning process }\end{array}\end{array}$ & 8 & 0.819 \\
\hline $\begin{array}{l}\text { Second dimension: } \\
\text { Importance of the flipped classroom strategy }\end{array}$ & 13 & 0.866 \\
\hline $\begin{array}{l}\text { Third dimension: } \\
\begin{array}{l}\text { Enjoyment of learning based on the flipped } \\
\text { classroom strategy }\end{array}\end{array}$ & 11 & 0.874 \\
\hline Total mark of the attitude scale & 32 & \\
\hline
\end{tabular}

The stability coefficients of the scale dimensions as per Cronbach's alpha method confirmed the stability of the attitude scale to a high degree, as seen in the table. 


\subsubsection{Teacher's guide to the flipped classroom strategy}

A teacher's guide was prepared to measure the skills of reciting the Holy Qur'an and the attitude towards the flipped classroom strategy. The guide focused on Surat Al-Naml, which is scheduled for first grade female students. The guide was prepared according to the ADDIE model due to its comprehensiveness, with five main stages: analysis, design, development, implementation, and evaluation.

We tested the note card on the two groups before and after the experiment and the t-test was applied to independent samples of the note card before starting the experiment. The test measured overall skills (intonation, fluency, and reciting), as shown in Table 8.

Table 8: Results of $t$-test for experimental and control groups in the pre-application of the note card

\begin{tabular}{|c|c|c|c|c|c|c|c|c|c|}
\hline \multirow[t]{2}{*}{$\begin{array}{l}\text { Note card } \\
\text { skill }\end{array}$} & \multirow[t]{2}{*}{ Group } & \multirow[t]{2}{*}{ No. } & \multirow[t]{2}{*}{$\mathbf{M}$} & \multirow[t]{2}{*}{ SD } & \multicolumn{2}{|c|}{$\begin{array}{l}\text { Homogeneity of } \\
\text { variance } \\
\text { Levene's test }\end{array}$} & \multirow[t]{2}{*}{ t-value } & \multirow[t]{2}{*}{$\begin{array}{l}\text { Sig. } \\
\text { level }\end{array}$} & \multirow[t]{2}{*}{ Stat. sig. } \\
\hline & & & & & Value & Sig. level & & & \\
\hline \multirow[t]{2}{*}{ Intonation } & Exp. & 24 & 6.46 & 3.19 & \multirow[t]{2}{*}{0.48} & 0.827 & \multirow[t]{2}{*}{0.512} & \multirow[t]{2}{*}{0.611} & \multirow[t]{2}{*}{ No sig. } \\
\hline & Ctrl & 24 & 6.92 & 3.01 & & (No sig.) & & & \\
\hline
\end{tabular}

\begin{tabular}{llllllllll}
\hline Fluency & Exp. & 24 & 1.96 & 1.04 & 1.24 & $\begin{array}{l}0.727 \\
\text { (No sig.) }\end{array}$ & 0.272 & 0.787 & No sig. \\
\cline { 2 - 5 } & Ctrl & 24 & 2.04 & 1.08 & & &
\end{tabular}

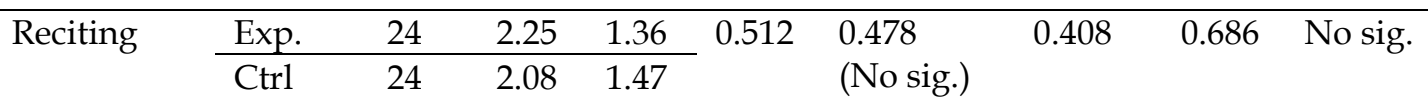

\begin{tabular}{llllllllll}
\hline $\begin{array}{l}\text { Total mark } \\
\text { of the card }\end{array}$ & Exp. & 24 & 10.6 & 4.20 & 0.267 & $\begin{array}{l}0.608 \\
\text { (No sig.) }\end{array}$ & 0.296 & 0.769 & No sig. \\
\cline { 2 - 5 } & Ctrl & 24 & $\begin{array}{l}11.0 \\
4\end{array}$ & 4.56 & & & & & \\
& & & & & & &
\end{tabular}

Note: M - mean; SD - standard deviation; sig. - significance

As seen in the table, the t-test values were not statistically significant, which confirms that the two groups were equal before the experiment. In addition, the Levene test values for homogeneity of variance were not statistically significant, which confirms the existence of homogeneity of variation between the scores of the two groups on the Qur'an reading skills note card before the experiment.

\section{Interpretation and Discussion of Findings}

The first subsidiary research question was: What is the effectiveness of the flipped classroom strategy in developing the skills of reciting the Holy Qur'an among first grade intermediate female students? The answer was determined by verifying the validity of the null hypothesis of no statistically significant difference at the 0.05 level between the average scores of the experimental group and the control group 
after applying the note card measurement of skills of reciting the Holy Qur'an for first grade female students.

We used the t-test for independent samples to discover the significance of difference between the average scores of the participants in the experimental and control groups after applying the note card skills of reciting the Qur'an as a whole and its component skills of intonation, fluency, and reciting, as shown in Table 9.

Table 9: $t$-values for the significance of difference between the average scores of the study groups in the post-application of the note card

\begin{tabular}{|c|c|c|c|c|c|c|c|c|}
\hline $\begin{array}{l}\text { Note card } \\
\text { skill }\end{array}$ & Group & No. & Mean & SD & $\begin{array}{l}\text { Degree } \\
\text { of } \\
\text { freedom }\end{array}$ & t-value & $\begin{array}{l}\text { Sig. } \\
\text { level }\end{array}$ & Stat. sig. \\
\hline \multirow{2}{*}{$\begin{array}{l}\text { Intonation } \\
\text { skill }\end{array}$} & Exp. & 24 & 18.38 & 1.31 & \multirow[t]{2}{*}{46} & \multirow[t]{2}{*}{9.77} & \multirow[t]{2}{*}{0.00} & Sig. at \\
\hline & Ctrl & 24 & 10.63 & 3.65 & & & & 0.05 \\
\hline \multirow{2}{*}{$\begin{array}{l}\text { Fluency } \\
\text { skill }\end{array}$} & Exp. & 24 & 5.38 & 0.77 & \multirow[t]{2}{*}{46} & \multirow[t]{2}{*}{5.61} & \multirow[t]{2}{*}{0.00} & Sig. at \\
\hline & Ctrl & 24 & 3.71 & 1.23 & & & & 0.05 \\
\hline \multirow{2}{*}{$\begin{array}{l}\text { Reciting } \\
\text { skill }\end{array}$} & Exp. & 24 & 7.50 & 0.83 & \multirow[t]{2}{*}{46} & \multirow[t]{2}{*}{10.18} & \multirow[t]{2}{*}{0.00} & Sig. at \\
\hline & Ctrl & 24 & 4.13 & 1.39 & & & & 0.05 \\
\hline \multirow{2}{*}{$\begin{array}{l}\text { Total mark } \\
\text { of the card }\end{array}$} & Exp. & 24 & 31.2 & 2.03 & \multirow[t]{2}{*}{46} & \multirow[t]{2}{*}{11.04} & \multirow[t]{2}{*}{0.00} & Sig. at \\
\hline & Ctrl & 24 & 18.46 & 5.30 & & & & 0.05 \\
\hline
\end{tabular}

Note: SD - standard deviation; sig. - significant/significance

The results indicate that the $t$-values were statistically significant at 0.05 , which shows a significant difference after applying the note card skills of reciting the Holy Qur'an for first grade female students. The null hypothesis is thus confirmed, and the alternative hypothesis is accepted, which states that there is a statistically significant difference at the 0.05 level in favor of the experimental group between the average scores of the two groups after applying the note card skills of reciting the Holy Qur'an for first grade female students.

In addition to the above test, we calculated eta squared $\left(\eta^{2}\right)$ to measure the effect of the flipped classroom strategy on developing the skills of reciting the Holy Qur'an. The results are shown in Table 10.

Table 10: Results of eta squared $\left(\eta^{2}\right)$, and the value of " $d$ " to show the effect of the flipped classroom strategy on developing the skills of reciting the Holy Qur'an

\begin{tabular}{lllllll}
\hline $\begin{array}{l}\text { Independent } \\
\text { variable }\end{array}$ & $\begin{array}{l}\text { Qur'an } \\
\text { reading } \\
\text { skills }\end{array}$ & t-value & $\begin{array}{l}\text { Degree } \\
\text { of } \\
\text { freedom }\end{array}$ & $\mathbf{n}^{2}$ value & $\begin{array}{l}\text { Effect } \\
\text { size } \\
\text { “d” } \\
\text { value }\end{array}$ & $\begin{array}{l}\text { Level of } \\
\text { effect }\end{array}$ \\
\hline $\begin{array}{l}\text { Flipped } \\
\text { classroom } \\
\text { strategy }\end{array}$ & $\begin{array}{l}\text { Intonation } \\
\text { skill }\end{array}$ & 9.77 & 46 & 0.675 & 2.88 & $\begin{array}{l}\text { Significant } \\
\text { effect }\end{array}$ \\
\cline { 2 - 7 } & $\begin{array}{l}\text { Fluency } \\
\text { skill }\end{array}$ & 5.61 & 46 & 0.406 & 1.65 & $\begin{array}{l}\text { Significant } \\
\text { effect }\end{array}$ \\
\cline { 2 - 7 } & $\begin{array}{l}\text { Reciting } \\
\text { skill }\end{array}$ & 10.18 & 46 & 0.692 & 2.99 & $\begin{array}{l}\text { Significant } \\
\text { effect }\end{array}$ \\
\cline { 2 - 7 } & $\begin{array}{l}\text { Total mark } \\
\text { of the card }\end{array}$ & 11.04 & 46 & 0.726 & 3.26 & $\begin{array}{l}\text { Significant } \\
\text { effect }\end{array}$ \\
\hline
\end{tabular}


The total effect of the flipped classroom strategy in the note card for observing the skills of reciting the Holy Qur' an as a whole was 3.26, which shows a high level of effect for the strategy in all skills.

The second subsidiary research question was: What is the effectiveness of the flipped classroom strategy in developing students' attitudes towards the strategy among first grade intermediate female students? The analysis was conducted by verifying the validity of the null hypothesis of no statistically significant difference at the 0.05 level between the average scores of the experimental and control groups after applying the note card skills of reciting the Holy Qur' an for first grade female students.

We used the t-test for the two samples to determine the significance of the difference between the average scores of the participants from the experimental and control groups after applying the note card scores for the importance and enjoyment of learning with the flipped classroom strategy. The results are indicated in Table 11.

Table 11: $t$-values to indicate the difference between the average scores of the experimental group pre- and post-application of the attitude scale of the flipped classroom strategy

\begin{tabular}{|c|c|c|c|c|c|c|c|c|}
\hline $\begin{array}{l}\text { Scale } \\
\text { dimension }\end{array}$ & $\begin{array}{l}\text { Applica- } \\
\text { tion }\end{array}$ & No. & $\mathbf{M}$ & SD & $\begin{array}{l}\text { Degree } \\
\text { of } \\
\text { freedom }\end{array}$ & t-value & $\begin{array}{l}\text { Sig. } \\
\text { level }\end{array}$ & $\begin{array}{l}\text { Stat. } \\
\text { sig. }\end{array}$ \\
\hline \multirow{2}{*}{$\begin{array}{l}\text { First } \\
\text { dimension: } \\
\text { Keenness to } \\
\text { use the flipped } \\
\text { classroom } \\
\text { strategy in the } \\
\text { learning } \\
\text { process }\end{array}$} & Pre-exp. & 24 & 11.88 & 2.01 & \multirow[t]{2}{*}{23} & \multirow[t]{2}{*}{19.99} & 0.00 & $\begin{array}{l}\text { Sig. at } \\
0.05\end{array}$ \\
\hline & Post-exp. & 24 & 21.75 & 1.36 & & & 0.00 & $\begin{array}{l}\text { Sig. At } \\
0.05\end{array}$ \\
\hline \multirow{2}{*}{$\begin{array}{l}\text { Second } \\
\text { dimension: } \\
\text { Importance of } \\
\text { the flipped } \\
\text { classroom } \\
\text { strategy }\end{array}$} & Pre-exp. & 24 & 18.96 & 3.01 & \multirow[t]{2}{*}{23} & \multirow[t]{2}{*}{26.88} & 0.00 & $\begin{array}{l}\text { Sig. at } \\
0.05\end{array}$ \\
\hline & Post-exp. & 24 & 37.04 & 1.85 & & & 0.00 & $\begin{array}{l}\text { Sig. at } \\
0.05\end{array}$ \\
\hline \multirow{2}{*}{$\begin{array}{l}\text { Third } \\
\text { dimension: } \\
\text { Enjoyment of } \\
\text { learning based } \\
\text { on the flipped } \\
\text { classroom } \\
\text { strategy }\end{array}$} & Pre-exp. & 24 & 16.67 & 2.93 & \multirow[t]{2}{*}{23} & \multirow[t]{2}{*}{22.56} & 0.00 & $\begin{array}{l}\text { Sig. at } \\
0.05\end{array}$ \\
\hline & Post-exp. & 24 & 30.54 & 2.00 & & & 0.00 & $\begin{array}{l}\text { Sig. at } \\
0.05\end{array}$ \\
\hline \multirow{2}{*}{$\begin{array}{l}\text { Total mark of } \\
\text { the attitude } \\
\text { scale }\end{array}$} & Pre-exp. & 24 & 47.50 & 6.68 & \multirow[t]{2}{*}{23} & \multirow[t]{2}{*}{29.06} & 0.00 & $\begin{array}{l}\text { Sig. at } \\
0.05\end{array}$ \\
\hline & Post-exp. & 24 & 89.33 & 4.05 & & & 0.00 & $\begin{array}{l}\text { Sig. at } \\
0.05\end{array}$ \\
\hline
\end{tabular}

Note: M - mean; SD - standard deviation; sig. - significant/significance 
The results indicate that the $t$-values were statistically significant at 0.05 , indicating that there is a statistically significant difference at that level between the average scores of the experimental group in the pre- and post-application of the scale of attitude towards the strategy of the flipped classroom as a whole and all its dimensions. The difference was in favor of the post-application. This suggests rejection of the null hypothesis of no statistically significant difference at the 0.05 level between the average scores of the experimental group and the control group after applying the note card skills of reciting the Holy Qur'an for first grade female students.

To determine the effectiveness of the independent variable in developing the attitude towards the flipped classroom strategy, we used the modified Blake's Gain Ratio equation. The results are shown in Table 12.

Table 12: Blake's adjusted gain ratio for measuring the attitude towards the flipped classroom strategy among first grade intermediate school female students

\begin{tabular}{|c|c|c|c|c|c|}
\hline Scale dimension & $\begin{array}{l}\text { Pre- } \\
\text { application } \\
\text { average }\end{array}$ & $\begin{array}{l}\text { Post- } \\
\text { application } \\
\text { average }\end{array}$ & Top mark & $\begin{array}{l}\text { Gain } \\
\text { mark }\end{array}$ & $\begin{array}{l}\text { Gain } \\
\text { amended } \\
\text { percentage }\end{array}$ \\
\hline $\begin{array}{l}\text { First dimension: } \\
\text { Keenness to use the } \\
\text { flipped classroom } \\
\text { strategy in the learning } \\
\text { process }\end{array}$ & 11.88 & 21.75 & 24 & 9.87 & 1.22 \\
\hline $\begin{array}{l}\text { Second dimension: } \\
\text { Importance of the } \\
\text { flipped classroom } \\
\text { strategy }\end{array}$ & 18.96 & 37.04 & 39 & 18.08 & 1.36 \\
\hline $\begin{array}{l}\text { Third dimension: } \\
\text { Enjoyment of learning } \\
\text { based on the flipped } \\
\text { classroom strategy }\end{array}$ & 16.67 & 30.54 & 33 & 13.87 & 1.27 \\
\hline $\begin{array}{l}\text { Total mark of the } \\
\text { attitude scale }\end{array}$ & 47.50 & 89.33 & 96 & 41.83 & 1.30 \\
\hline
\end{tabular}

The adjusted gain percentage for the total score of the attitude scale was 1.30. This value confirms the effectiveness of developing a positive attitude towards the flipped classroom strategy among first grade intermediate female students.

Pearson correlation coefficients were calculated for the relationship between reciting skills and attitude towards the strategy among participants of the experimental group. The results are presented in Table 13. 
Table 13: Pearson correlation coefficients for the relationship between reciting skills and attitude towards the strategy among participants of the experimental group

\begin{tabular}{lllll}
\hline Variable & No. & $\begin{array}{l}\text { Correlation } \\
\text { coefficient }\end{array}$ & $\begin{array}{l}\text { Significance } \\
\text { level }\end{array}$ & $\begin{array}{l}\text { Statistical } \\
\text { significance }\end{array}$ \\
\hline Qur'an recitation skills & 24 & 0.646 & 0.001 & $\begin{array}{l}\text { Significant } \\
\text { at } 0.05\end{array}$ \\
\hline $\begin{array}{l}\text { Attitude towards flipped } \\
\text { classroom strategy }\end{array}$ & 24 & & & \\
\hline
\end{tabular}

Table 13 shows a positive statistical correlation significance at 0.05 for the skills of reciting the Holy Qur'an, along with the attitude towards the flipped classroom strategy among the experimental group after they were taught using the strategy. Therefore, this result rejects the third null hypothesis of no statistically significant difference at the 0.05 level between the average scores of the experimental group and the control group after applying the note card skills of reciting the Holy Qur'an to participants.

In general, the findings of the research are consistent with previous studies. For example, Kim et al. (2021) revealed the importance of the student's involvement and self-regulation in flipped learning, and that well-designed flipped learning opportunities provide the student with the ability to demonstrate autonomy and realize better achievement.

\section{Results}

Results related to the first subsidiary question revealed the superiority of the experimental group, which studied using the flipped classroom strategy, over the control group in the note card measurements of Holy Qur'an recitation skills (intonation, fluency, and reciting) separately and as a whole. The results agree with earlier studies that have demonstrated the effectiveness of the flipped classroom strategy in different study subjects (Al-Shehri, 2018; Al-Zayoud, 2017; Othman \& Al-Zubaidi, 2018).

Results for the second subsidiary question showed that the average scores of the experimental group pre- and post-application in the scale of attitude towards the flipped classroom strategy were in favor of the post-application scores. This was reflected in how participants chose their way of learning according to their ability and how they guided each other and evaluated themselves. This result is consistent with the results of studies that have proved the effectiveness of the flipped classroom strategy (Al-Rous et al., 2016).

The hypothesis related to the third subsidiary question was that there is no statistically significant correlation at the 0.05 level between the skills of reciting the Holy Qur'an and attitude towards the flipped classroom strategy among first grade female students after teaching them using the flipped classroom strategy. Pearson's correlation coefficient was used to verify the statistical correlation significance between the scores of the experimental group after applying the Holy Qur'an recitation skills note card and their scores of the attitude scale towards the flipped classroom strategy. 


\section{Conclusion}

The study was conducted in the first semester of the academic year 2020-2021 on a purposeful sample of first grade intermediate female students at Al-Hassan School, affiliated to East Dammam Office in the KSA, one of the private schools where the Classera educational platform is available. The results revealed that teaching with the flipped classroom strategy helps to develop skills and the ability to apply them practically in proper performance. It provides the opportunity to learn outside the classroom to develop various skills away from the fear and dread that may hinder the learning process, while at the same time increasing motivation to learn. The flipped classroom strategy thus provides the opportunity for female students to correct each other's mistakes, as well as to seek to use modern resources available through the internet.

\section{Recommendations}

Based on our findings, we present recommendations to the following groups of people involved in the teaching and learning process.

\subsection{Curriculum planners of Sharia sciences}

Modern technologies need to be used in designing various Islamic educational curricula according to modern teaching methods, such as the flipped classroom strategy, to develop the skills of reciting the Holy Qur'an. In addition, educational guides need to be prepared for various Islamic educational curricula regarding the flipped classroom strategy.

\subsection{Supervisors of Sharia sciences}

Supervisors of Islamic education should have access to various assessment tools, such as the note card, to measure the skills of reciting the Qur' an, along with scales to measure female students' attitude towards their learning. Besides this, they should train teachers on how to formulate these tools.

\subsection{Male and female teachers of the Holy Qur'an}

Islamic education teachers should be provided with a procedural guide according to the flipped classroom strategy to keep pace with modern technological attitudes in teaching methods, in line with the digital transformation in the KSA's Vision 2030 in the field of education. Furthermore, Islamic education teachers should be provided with the note card as a tool to evaluate the skills of students and as a measure of attitude towards the strategy. Lastly, training should be given to Islamic education teachers in general and Qur'an teachers in particular on modern teaching strategies, including the flipped classroom strategy.

\subsection{Female students}

A learning environment should be provided that allows dealing with technology through the flipped classroom strategy, thus developing students' abilities and skills in the learning process and their attitude towards the strategy. In addition, educational courses should be provided to develop the awareness of intermediate school female students about the effectiveness of the flipped classroom strategy in developing the skills of reciting the Holy Qur'an, and the attitude towards the strategy. 


\section{Suggestions for Further Research}

Arising from the results and recommendations, we suggest conducting further research into the following areas in the field of Qur'an learning and teaching.

- The effectiveness of the flipped classroom strategy in developing the skills of reciting the Holy Qur'an among secondary school female students.

- Attitudes of secondary school female students towards the flipped classroom strategy.

- The effectiveness of modern strategies other than the flipped classroom strategy in developing the skills of reciting the Holy Qur'an.

- The reasons for weak Qur'an recitation skills among intermediate school female students.

- A study of the correlation between the skills of reciting the Qur'an and attitude towards the flipped classroom strategy among secondary school female students.

\section{References}

Aaron, T. A. (2015). faeiliat namudhaj altaealum almaqlub fi altahsil wal'ada' limaharat altaealum al'iiliktrunii ladaa [The effectiveness of the flipped learning model on the achievement and performance of e-learning skills for undergraduate students]. almutamar alduwaliu al'awal: altarbit afaq mustaqbalia, Al-Baha University, Al-Baha, pp. 686-703. http://education.arab.macam.ac.il/article/567

Abanmi, F. A. (2016). 'athar aistikhdam astiratijiat alsafi almaqlub fi tadris altafsir fi altahsil aldirasii walaitijah nahw almadat ladaa tulaab alsafi althaani althaanawi [The impact of using the flipped classroom strategy in teaching interpretation in achievement and the attitudes toward interpretation at second grade secondary students]. majalat alqira' at walmaerifati: aljameiat almisriat lilqira'at walmaerifa, 173, 21-48. http:// search.mandumah.com/ Record/727219

Al-Harthy, I. (2012). faeiliat barnamaj muqtarah fi tiknulujia altaelim qayim ealaa altaelim almudmaj fi tanmiat maharat alaistikhdam walaitijahat nahwaha ladaa talibat kuliyat altarbiti (risalat majistir ghayr manshuratin) [The effect of a flipped learning-based learning environment on the development of e-courses production skills among postgraduate female students (Unpublished master's thesis)]. jamieat 'um alquraa, makat, almamlakat alearabiat alsaeudiati. https://drive.uqu.edu.sa/_/jep/files/11-1/jep-11-1-2-2.pdf

Al-Juhani, A. B. A. K. (2017). faeiliat aistikhdam astiratijiat taqasiy alwib litadris al'ahya' fi tanmiat altafkir altawlidii walaitijah nahwaha ladaa talibat alsafi althaani thanaway [The effectiveness of using Webquest Strategy for teaching biology on developing generative thinking \& their attitudes towards Webquest for second secondary year students]. almajalat altarbawiat alduwaliat almutakhasisa, 6(3), 210226. http://search.mandumah.com/Record/845409

Al-Nafi'i, A. R. A. A. (2007). bina' mawazin al'iitijahat biaistikhdam 'uslub altaqdir aljameii (likirti): 'iistifta' eawayiq alnashat almadrasii namudhaja [Building the scales of attitudes using the collective assessment method (Likert): A survey of obstacles to school activity as a model]. majalat albuhuth alnafsiat waltarbawia, 22(1), 323-352. http:// search.mandumah.com/Record/117097

Al-Rous, A., Mounir, A., \& Amara, N. A. (2016). faeiliat alsafi almaqlub fi tanmiat altahsil aldirasii ladaa talibat kuliyat altarbiat bijamieat qatar waitijahatihina nahwahu [Effectiveness of flipped classroom on academic achievement and students' attitude in Faculty of Education at Qatar University]. almajalat altarbawiat 
alduwaliat almutakhasisati: almajmueat alduwaliat lilaistisharat waltadrib, 49, 36-38. http:/ / search.mandumah.com/Record/844900

Al-Salim, N. M. (2017). aleawamil dhat alealaqat bialrusub fi muqarar alquran alkarim litalibat jamieat al'iimam muhamad bin sueud al'iislamia (risalat majistir ghayr manshuratin) [Factors related to failure in the Holy Qur'an course for female students of Imam Muhammad bin Saud Islamic University (Unpublished master's thesis)]. jamieat al'iimam muhamad bin sueud al'iislamiati, alriyad. http:// search.mandumah.com/Record/782641

Al-Shehri, A. A. R. M. (2018). 'athar tadris alquran alkarim biaistikhdam namat altaealum almudmaj ealaa tashih altilawat litulaab halaqat al'akadimiat alquraniat alealamiati [The effectiveness of using cognitive trips via the web in developing some skills of reciting the Holy Qur'an among middle school students in the Holy Qur'an memorization schools in Al-Namas Governorate]. almajalat alduwaliat lildirasat altarbawiat walnafsia, 12, 186-222. http://search.mandumah.com/Record/885903

Al-Zahrani, A. O. (2018). 'athar tawzif alkharayit aldhihniat fi biyat altaealum al'iiliktrunii ealaa tanmiat baed maharat tilawat alquran alkarim ladaa talibat kuliyat aleulum waladab [Effect of utilizing mental maps in an e-learning environment on developing some skills for Holy Quran recitation for female students at the Faculty of Sciences and Arts]. almajalat alduwaliat lileulum altarbawiat walnafsiati: almuasasat alearabiat lilbahth aleilmii waltanmiat albasharia, 11, 225-323. http:// search.mandumah.com/Record/880115

Al-Zayoud, E. K. F. (2017). faeiliat aistikhdam alkitaab al'iiliktrunii fi 'iiksab talabat alsafi althaani al'asasii maharat tilawat alquran alkarim fi mudiriat tarbiat alzarqa' althaania (risalat majistir ghayr manshuratin) [The effectiveness of using the electronic book in providing second-grade students with the skills of reciting the Noble Qur'an in the second Zarqa Education Directorate (Unpublished master's thesis)]. aljamieat alhashimiati, alzarqa'. http://search.mandumah.com/Record/857418

Al-Zoubi, I. A. (2013). taqyim 'ada' tilawat tulaab alsafi alkhamis al'asasii fi daw' almustawayat almieyariat litajwid alquran alkarim fi tarbiat qasabat almufarqi [Evaluation of fifth graders' performance in reciting the Holy Quran in Mafraq in light of the standard criteria]. almajalat al'urduniyat fi aleulum altarbawia, 9(2), 187197. http://journals.yu.edu.jo/jjes/Issues/2013/Vol9No2/5.pdf

Bergmann, J., \& Sams, A. (2012). Flip your classroom: Reach every student in every class every day.

https://www.rcboe.org/cms/lib/GA01903614/Centricity/Domain/15451/Flip _Your_Classroom.pdf

Caudill, N. (2014). Pre-service teachers' perceptions of a flipped classroom: A study of undergraduates enrolled in an applied child development course (Unpublished master's thesis). North Carolina State University. https:// repository.lib.ncsu.edu/bitstream/handle/1840.16/9699/etd.pdf

Cooper, M. S. (1973). Modified Hypernetted-Chain Equation for the Screened Coulomb. Physical Review, 7(1). https://doi.org/10.1103/PhysRevA.7.1

Fulton, K. (2012). Upside down and inside out: Flip your classroom to improve student learning. Learning \& Leading with Technology, 39(8), 12-17. https://files.eric.ed.gov/fulltext/EJ982840.pdf

Hava, K. (2020). The effects of the flipped classroom on deep learning strategies and engagement at the undergraduate level. Participatory Educational Research, 8(1), 379-394.

https://www.researchgate.net/publication/345994907_The_effects_of_the_flip 
ped_classroom_on_deep_learning_strategies_and_engagement_at_the_undergra duate_level

Herreid, C., \& Schiller, N. (2013). Case studies and the flipped classroom. Journal of College Science Teaching, 42(5), 62-66. https://flippedlearning.org/definition-of-flippedlearning

Huu Vuong, N. H. A., Tan, C. K., \& Lee, K. W. (2018). Students' perceived challenges of attending a flipped EFL classroom in Viet Nam. Theory and Practice in Language Studies, 8(11), 1504-1510. http://dx.doi.org/10.17507/tpls.0811.16

Johnson, L. (2012). Effect of the flipped classroom model on a secondary computer applications course: Student and teacher perceptions, questions and student achievement (Doctoral dissertation).

University of Louisville. https:/ / theflippedclassroom.files.wordpress.com/2012/04/johnson-renner2012.pdf

Kim, H. N., So., H.-J., \& Joo, Y. J. (2021). Flipped learning design fidelity, self-regulated learning, satisfaction, and continuance intention in a university flipped learning course. Australasian Journal of Educational Technology, 37(4), 1-19. https://ajet.org.au/index.php/AJET/article/view/6046

Kingdom of Saudi Arabia (KSA). (2030). Vision 2030. https://www.vision2030.gov.sa/

Kingdom of Saudi Arabia. The Ministry of Education. (2007). wathiqatan manhaj mawadi aleulum alshareiat lilmarhalatayn alaibtidayiyat walmutawasitat fi altaelim aleami $[A$ curriculum document for Sharia science subjects for the primary and intermediate stages in general education]. alriyad, almamlakat alearabiat alsaeudiati: markaz altatwir altarbwi, al'iidarat aleamat lilmanahij.

https://drive.uqu.edu.sa/_/hmkalthem/files/\%D8\%A7\%D9\%84\%D9\%84\%D9

\%88\%D8\%A7\%D8\%A6\%D8\%AD\%20\%D9\%88\%D8\%A7\%D9\%84\%D8\%A7\%D9

\%86\%D8\%B8\%D9\%85\%D8\%A9/E\%D9\%88\%D8\%AB\%D9\%8A\%D9\%82\%D8\%A

9\%20\%D8\%AA\%D8\%AF\%D8\%B1\%D9\%8A\%D8\%B3\%20\%D8\%A7\%D9\%84\%D8

\%B9\%D9\%84\%D9\%88\%D9\%85\%20\%D8\%A7\%D9\%84\%D8\%B4\%D8\%B1\%D8\%B 9\%D9\%8A\%D8\%A9.pdf

Marlow, C. (2012). The effect of the flipped classroom on student achievement and stress. https://scholarworks.montana.edu/xmlui/bitstream/handle/1/1790/Marlowe C0812.pdf

Matar, Y. K. (2018). 'athar barnamaj muhawsib fi tanmiat maharat altilawat ladaa tulaab markaz alquran alkarim bialkuliyat aljamieiat lileulum altatbiqiati [The effects of a computerized program in developing the skills of recitation for the performance of students of the Holy Quran Center in colleges of associations for science and applications]. majalat jamieat al'iisra' lileulum al'iinsaniati: jamieat al'iisra', 5, 245267. http://search.mandumah.com/Record/908869

Merrill, J. E. (2015). The flipped classroom: An examination of veteran teachers' practices when flipping their classrooms for the first time [Doctoral dissertation, Texas A \& $\mathrm{M}$ University]. https:// oaktrust.library.tamu.edu/handle/1969.1/155313

Nashawati, A. M. (2003). eilm alnafs altarbawii (ta4) [Educational psychology (4th ed.)]. eaman, al'urdunu: Dar alfurqan lilnashr waltawzie.

Othman, M. A. O., \& Al-Zubaidi, M. A. H. (2018). The impact of using learning management system (Blackboard) on developing the skills of recitation and Tajweed of the Holy Qur'an among students of Islamic studies at King Faisal University. Al-Quds Open University Journal for Research and Studies: Al-Quds Open University, 44, 219-233. http:/ / search.mandumah.com/Record/921681

Prieto, A., Barbarroja, J., Álvarez, S., \& Corell, A. (2021). Eficacia del modelo de aula invertida (flipped classroom) en la enseñanza universitaria: Una síntesis de las mejores evidencias [Effectiveness of the flipped classroom model in university 
education: A synthesis of the best evidence]. Revista de Educación, 391, 147-177. https:// doi.org/10.4438/1988-592X-RE-2021-391-476

Shaheen, M., Shendi, I., \& Alloush, A. (2015). 'asbab duef talabat tukhasis taelim altarbiat al'iislamiat fi jamieat alquds almaftuhat fi maharat altilawat waltajwid waiqtirah barnamaj lieilajiha [Reasons for the weakness of the students of Islamic education at Al-Quds Open University in mastering the skills of reading and reciting the Holy Quran and a proposed remedial program]. majalat jamieat alquds almaftuhat lil'abhath waldirasat altarbawiat walnafsiati: jamieat alquds almaftuha, 3(9), 13-44. http:// search.mandumah.com/Record/676825

Siddiq, H. (2012). aliatijahat min manzur eilm aliajtimaei [Trends from a sociological perspective]. majalat jamieat dimashaqa, 28(3-4), 299-322. http://www.damascusuniversity.edu.sy/mag/human/images/stories/32012/a/299-322.pdf

Smith, J. P. (2015). The efficacy of a flipped learning classroom (Doctoral dissertation). McKendree University, Lebanon, Illinois.

https://www.proquest.com/openview/3f79da89d7efc6979c4c1ded7e5490af/1? pq-origsite $=$ gscholar\&cbl $=18750$

UC Riverside. (2021). Flipped learning. https:/ / facdev.ucr.edu/flipped-learning 